\title{
Influence of physicochemical properties of Brazilian serpentinites on the leaching process for indirect $\mathrm{CO}_{2}$ mineral carbonation
}

\author{
Gretta L. A. F. Arce ${ }^{\mathrm{a}, \mathrm{b}, *}$, Turibio G.S. Neto ${ }^{\mathrm{a}}$, I. Ávila ${ }^{\mathrm{b}}$, Carlos M.R. Luna ${ }^{\mathrm{b}}$, José C. dos Santos ${ }^{\text {a }}$, João A. Carvalho Jr ${ }^{\mathrm{b}}$ \\ a Combustion and Propulsion Associated Laboratory, Brazilian Space Research Institute (LCP/INPE), Brazil \\ b Combustion and Carbon Capture Laboratory, Energy Department, São Paulo State University (LC3/DEN/UNESP), Brazil
}

\section{A R T I C L E I N F O}

\section{Article history:}

Received 23 May 2016

Received in revised form 10 November 2016

Accepted 21 January 2017

Available online 24 January 2017

\section{Keywords:}

Serpentinite

Leaching

Physicochemical properties

Indirect mineral carbonation

Reactivity

\begin{abstract}
A B S T R A C T
pH-swing mineral carbonation is kinetically favorable and requires a short reaction time. It must also obtain a high extraction rate for reactive elements in the leaching process. The main purpose of this study is to investigate the behavior of different serpentinite rocks in the leaching processes; the reactivity of Brazilian serpentinite rocks (such as: S-GO and S-MG) is analyzed based on physicochemical properties in order to understand their relationship to leaching efficiency. Surface area-to-volume ratio $\left(\mathrm{S}_{\mathrm{BET}} / \mathrm{V}_{\mathrm{p}}\right)$ and metals-to-silicon ratio $(\Sigma(\mathrm{Mg}, \mathrm{Ca}) / \mathrm{Si})$ were used to measure reactivity. Leaching was carried out to determine $\mathrm{Mg}$ and Fe extraction. Reaction conditions for both serpentinite rocks were: $355-250 \mu \mathrm{m}$ particle size, $4 \mathrm{M} \mathrm{HCl}$ concentration, $100{ }^{\circ} \mathrm{C}$, and $2 \mathrm{~h}$ of reaction time. Characterization results show that both serpentinite rocks (S-GO and S-MG) have high magnesium (Mg) content. $\mathrm{S}_{\mathrm{BET}} / \mathrm{V}_{\mathrm{p}}$ was 36 for S-GO and 29 for S-MG, while $\Sigma(\mathrm{Mg}, \mathrm{Ca}) / \mathrm{Si}$ was 2.64 for S-GO and 1.20 for S-MG. These results suggest that S-GO is approximately 50\% more reactive than S-MG, and that S-MG is limited by low accessible surface $\left(\mathrm{S}_{\mathrm{BET}} / \mathrm{V}_{\mathrm{p}}\right)$ and the high mineralogical complexity $(\Sigma(\mathrm{Mg}, \mathrm{Ca}) / \mathrm{Si})$. Leaching results confirmed the reactivity; $\mathrm{Mg}$ and Fe extraction from S-GO was $94 \pm 1 \%$. However, results for S-MG were $34 \%$ for $\mathrm{Mg}$ and $60 \%$ for Fe. In order to increase the reactivity of S-MG, particle size was reduced to 75-63 $\mu \mathrm{m}$. Even though S-MG was mechanically activated, $\mathrm{Mg}$ and Fe extraction has not increased significantly.
\end{abstract}

(c) 2017 Elsevier B.V. All rights reserved.

\section{Introduction}

Carbon dioxide $\left(\mathrm{CO}_{2}\right)$ emission from fossil fuel combustion is the greatest factor in the current increase in atmospheric $\mathrm{CO}_{2}$ concentration. The concentration of $\mathrm{CO}_{2}$ in the atmosphere reached $401 \mathrm{ppm}$ in 2016 (Arce et al., 2014; Edenhofer et al., 2014). Due to the growing worldwide demand for energy, fossil fuel will continue to be the major source of energy in the near future. Fossil fuels have many advantages, principally its high energy density and low operating cost (Olajire, 2013).

Carbon Capture and Storage by Mineralization (CCSM) is a safe technology that is known to store $\mathrm{CO}_{2}$ permanently in the form of environmentally stable carbonates (Gadikota et al., 2014a; Sanna et al., 2014a, 2014b, 2013a; Styles et al., 2014). Today, there are two types of CCSM approaches: i) in situ or direct mineral carbonation; and ii) ex-situ or indirect mineral carbonation. Indirect mineral carbonation could make a great contribution to $\mathrm{CO}_{2}$ storage; however, there are many challenges to implement it on an industrial scale (Chang et al., 2012; Gadikota

\footnotetext{
* Corresponding author at: Brazilian Space Research Institute (INPE), Combustion and Propulsion Associated Laboratory (LCP), Rodovia Presidente Dutra, km 40, Cachoeira Paulista, SP CEP 12630-000, Brazil.

E-mail addresses: grettagaf@yahoo.es, gretta@lcp.inpe.br (G.L.A.F. Arce).
}

et al., 2015; Hemmati et al., 2014a; Sanna et al., 2013b; Styles et al., 2014).

There have been several studies on indirect mineral carbonation in which the highest carbonation efficiencies were obtained through the pH-swing method (Dri et al., 2013; Hemmati et al., 2014a; Sanna et al., 2013a, 2013b; Teir et al., 2007b). As stated by Hemmati et al. (2014b), this method is kinetically favorable and requires a short reaction time. It also allows the separation and recovery of products with a high level of purity ( silica, iron oxides and carbonates) that could be potentially used in a wide range of sectors, hence reducing the emissions from production of such materials (Alexander et al., 2007; Azdarpour et al., 2015; Bobicki et al., 2012; Sanna et al., 2013a, 2013b, 2012). Nonetheless, due to the high cost of the process, it will not be economically feasible for $\mathrm{CO}_{2}$ storage without considering the utilization of such products (Hemmati et al., 2014a).

Lately, indirect mineral carbonation has focused on using silicate rocks because they are common throughout the world. However, the pH-swing method did not have good kinetics for all silicate rocks. In many cases, the lowest extraction rate of the reactive elements was reached (Mg, Ca, and Fe) (Daval et al., 2013; Meyer et al., 2014; Park and Fan, 2004; Sanna et al., 2014a; Sanna et al., 2013a, 2013b; Van Essendelft and Schobert, 2010). Since this method is quite costly, it must obtain a high extraction rate of reactive elements. Thereby, the 
reactivity of silicates rocks must be carefully assessed. A detailed appraisal may greatly improve CCSM efficiency (Erlund et al., 2016; Gadikota et al., 2014b; Styles et al., 2014).

Currently, researchers have many challenges. One of the most important is to improve the reactivity of these silicate rocks in order to reduce the energy requirement and, consequently, the cost involved in the process (Bobicki et al., 2015; Fricker and Park, 2013; Hemmati et al., 2014b; Lackner et al., 1995; Meyer et al., 2014; Olajire, 2013; Park and Fan, 2004; Sanna et al., 2014b; Sanna et al., 2013a, 2013b; Wang and Maroto-Valer, 2011a, 2011b). For these reasons, pretreatment methods found in other published studies for indirect mineral carbonation, are being combined, such as mechanical activation, thermal activation, and chemical treatment.

While there have been many studies in this field, there is still a discrepancy regarding $\mathrm{CO}_{2}$ capture potential of silicate rocks. In order to get a better understanding of whether or not silicate rocks are adequate, recently Gadikota et al. (2014b); Lacinska et al. (2016); Lavikko and Eklund (2016); Styles et al. (2014) have suggested that silicate rocks must be characterized more carefully because their mineralogy varies widely. The characterization must consider pore structure, surface area $\left(\mathrm{S}_{\mathrm{BET}}\right)$, origin, subsequent metamorphic changes, and crystal structure of the minerals in the rocks.

According to Assima et al. (2014), when reactivity is considered, materials for direct mineral carbonation based on carbonation potential $\left(\mathrm{R}_{\mathrm{CO} 2}\right)$ are not similar. This is due to the fact that reactivity is the product of physicochemical properties. In pH-swing mineral carbonation, the selection of materials is still realized on carbonation potential $\left(\mathrm{R}_{\mathrm{CO} 2}\right)$ proposed by Goff et al. (2000) which was based strictly on their $\mathrm{Mg}$, Ca, and Fe contents. It is worth mentioning that rocks contain several minerals in their structure, which can cause the rock to be more or less reactive. This means that the reaction condition may not be similar for all materials. Therefore, to assess the reactivity of the material for indirect mineral carbonation, $\mathrm{Mg}$, Ca, and Fe contents, and other important criteria such as $\mathrm{Si}$ content, crystal structure, and textural properties, which are intrinsically related, must also be considered.

The main objective of this study was to investigate the behavior of different types of Brazilian serpentinite rocks on leaching for their use in $\mathrm{pH}$ swing mineral carbonation. The reactivity of serpentinite rocks is analyzed based on physicochemical properties. Thus textural properties, mineral composition, and crystal structure are studied, as well as the surface area-to-volume ratio $\left(\mathrm{S}_{\mathrm{BET}} / \mathrm{Vp}\right)$ and metals-to-silicon ratio $(\Sigma(\mathrm{Mg}, \mathrm{Ca}) / \mathrm{Si})$ were used, in order to understand their interrelationship with leaching efficiency.

\section{Materials and methods}

\subsection{Materials}

Two types of serpentinite rock (S) were chosen for this study. A waste rock of the asbestos fiber production from Minaçu Mine was selected, located in Cana Brava in the state of Goiás in Brazil. This rock was identified as S-GO. The other serpentinite was a rock from a factory that mines serpentinite for industrial use from Nova Lima mine located in the state of Minas Gerais in Brazil. This rock was identified as S-MG. Both S-GO and S-MG were provided in the form of rocks, and their average dimensions were $31.0 \times 15.5 \mathrm{~cm}$ and $15.0 \times 10.0 \mathrm{~cm}$. See Fig. A1a (S-GO) and b (S-MG).

A ball crusher was used in order to reduce their size. S-GO and S-MG were ground in a jar mill with alumina spheres of different sizes. Calcined alumina spheres were used since they have a hardness of approximately 9 mohs. Particle size was classified for characterization analysis after the material was ground, using an ASTM 200 mesh ( $75 \mu \mathrm{m})$ and a 230 mesh $(63 \mu \mathrm{m})$, so that the fraction had grains between these two sizes. For the leaching experimental test, two particle sizes were used. Thus, to obtain average particle sizes of $69 \mu \mathrm{m}(63-75 \mu \mathrm{m})$ and
$302 \mu \mathrm{m}$ (250-355 $\mu \mathrm{m})$, ASTM mesh numbers 230-200 and 45-60 were used, respectively.

\subsection{Characterization methods}

Samples of each serpentinite rock were prepared and underwent the following analyses: $\mathrm{Hg}$ intrusion porosity (MIP); $\mathrm{N}_{2}$ adsorption surface area; thermogravimetric analysis (TGA); X-ray diffraction (XRD); Scanning electron microscope with dispersive X-ray energy spectrometry (MEV-EDS); wavelength dispersion sequential fluorescence (XRF); and inductively coupled plasma optical emission spectroscopy (ICPOES).

Mercury intrusion porosimetry (MIP) and $\mathrm{N}_{2}$ adsorption surface area are well known techniques that have been used to analyze the structure and volume of pores (micro, meso, and macropores). They can evaluate factors such as fluid and ion permeability within particles (Das et al., 2014; Ramli et al., 2013; Zeng et al., 2014). Pore structure, macropore volume, and porosity of materials were determined through MIP analysis in a series 33 PoreMaster. Before being tested, materials were dried in an oven for $12 \mathrm{~h}$ at $100{ }^{\circ} \mathrm{C}$. After being dried, $250 \pm$ $10 \mathrm{mg}$ samples were collected in a $\mathrm{P} / \mathrm{N} 74122$ penetrometer with $2 \mathrm{~mm}$ D.I. and $0.5 \mathrm{~cm}^{3}$ vol. Afterwards, a NOVA series Micrometromics Quantacroms $\mathrm{N}_{2}$ adsorption surface area measurer was used to evaluate BET surface area and volume of mesopores. $170 \pm 10 \mathrm{mg}$ samples were inserted into the analyzer cell. The samples then underwent a thermal surface cleaning treatment at $200{ }^{\circ} \mathrm{C}$ for $3 \mathrm{~h}$ in primary vacuum.

Thermogravimetric analyses (TGA) were carried out to assess the thermal behavior of both serpentinite rocks and residues obtained after the leaching process. These TGA were carried out in a TA Instrument SDT TGA-DSC Q600 simultaneous system. The sample mass used was approximately $30 \pm 2 \mathrm{mg}$, with a $5 \times 5 \mathrm{~mm}$ alumina crucible employed for all tests. A dynamic nitrogen atmosphere was applied as purge gas, using $100 \mathrm{~mL} / \mathrm{min}$ flow rate and $10^{\circ} \mathrm{C} / \mathrm{min}$ heating rate. Temperatures were set between 30 and $1000{ }^{\circ} \mathrm{C}$.

Mineralogical composition was determined using a PANalitical X'pert3 Powder model X-ray diffraction analyzer (XRD). This device uses $\mathrm{Cu} K \alpha$ radiation in a range of 6-90 ${ }^{\circ} 2 \theta$. Diffractograms obtained were processed using the HighScore Plus software. A mass of approximately $1 \pm 0.5 \mathrm{~g}$ was used for this analysis.

SEM-EDS analysis was carried out to determine the materials' morphology and elemental distribution. A Zeiss EVO LS 15 equipped with an EDS/EBDS Oxford INCA Energy 250 system (Oxford Instruments, Abingdon, Oxfordshire, UK) was used for the scanning electron microscope analysis. Dispersive energy microanalysis was executed. It operated between 0.2 and $30 \mathrm{kV}$ and employed an Everhart-Thornley secondary electron detector, $8.5 \mathrm{~mm}$ away from the samples.

Sequential fluorescence with wavelength dispersion (XRF) was used for quantitative analyses of chemical composition of the materials. It was carried out using a PANalytical Axios MAX-Advanced model, a device with $4.0 \mathrm{~kW}$ operating power and $60 \mathrm{kV}$ agitation. This analyzer was used to perform a quantitative elemental chemical analysis of boron (B) and uranium (U). For this analysis, a $1 \pm 0.2 \mathrm{~g}$ sample of each material was used.

ICP-OES analyses were conducted to determine elemental composition with an Arcos Spectro model inductively coupled plasma optical emission spectroscope. A $250 \pm 10 \mathrm{mg}$ powder sample of each material was employed.

\subsection{Leaching experimental tests}

To evaluate the influence of the physicochemical properties on leaching processes, the same reaction conditions were employed for S-GO and S-MG. The reaction conditions considered were stoichiometric mass/volume ratios, $250-355 \mu \mathrm{m}$ particle size, $4 \mathrm{M} \mathrm{HCl}$ concentration, and $100{ }^{\circ} \mathrm{C}$ temperature. 

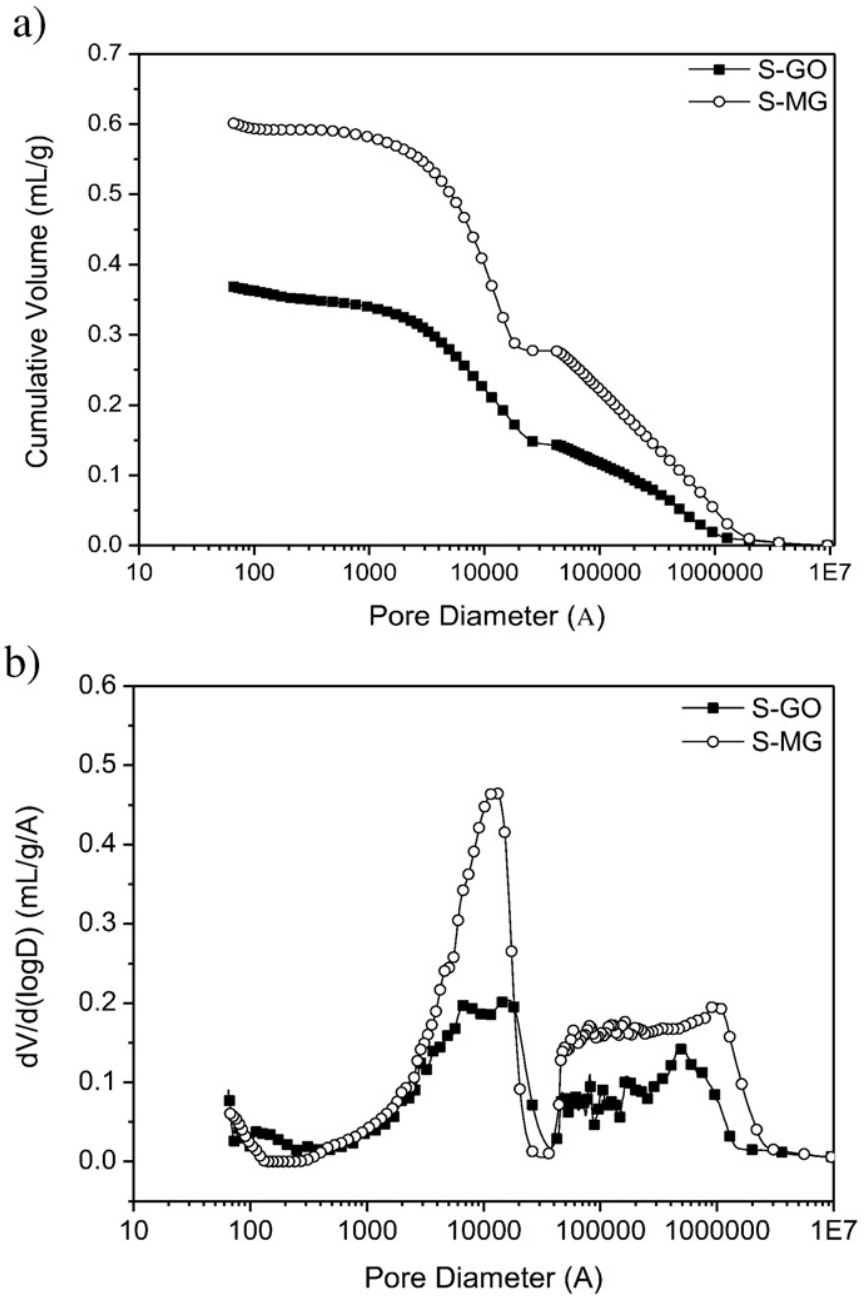

Fig. 1. Mercury porosity analysis of the two different serpentinite rocks: (a) Cumulative intrusion volume curve; (b) Curve of the difference of $\mathrm{V}$ by the difference of the Log of pore diameter.

Stoichiometric mass/volume ratios for the experimental tests were $146 \mathrm{~g} / \mathrm{L}$ for S-GO and $168 \mathrm{~g} / \mathrm{L}$ for S-MG. Initially, acid solutions were inserted into a $500 \mathrm{~mL}$ vessel reactor and heated to a specified temperature. Once the acid solution was heated, the powder was added to the vessel reactor, which was equipped with a Graham condenser to avoid $\mathrm{HCl}$ loss by evaporation, as well as a thermocouple for temperature control; it was continuously agitated with a magnetic stirrer set at 600$700 \mathrm{rpm}$. The leaching process was maintained for $2 \mathrm{~h}$ based on other studies (Hemmati et al., 2014a; Teir et al., 2007b; Van Essendelft and Schobert, 2009).

After each leaching experimental test $(\mathrm{T})$, two products were obtained: a precipitate or solid residue $(\mathrm{R})$ and a leachate solution $(\mathrm{L})$. The precipitate was separated from the liquid through vacuum filtration. Following each experiment, residues (R) were dried for $2 \mathrm{~h}$ at $105^{\circ} \mathrm{C}$. Then, TG/DTG and XRD analyses were carried out in order to observe the structural modifications from serpentinite rocks after the leaching process.

Leachate solutions (L) were analyzed by ICP-OES to obtain $\mathrm{Mg}$, Fe, and $\mathrm{Si}$ concentrations and to determine extraction percentage. $\mathrm{Mg}, \mathrm{Fe}$, and $\mathrm{Si}$ extractions in the leachate solution (L) were calculated based on their "in natura" contents within serpentinite rocks, according to the following equations, from Eqs. (1) to (3):

$$
\begin{aligned}
& X_{M g}=\frac{V_{S O L} \times C_{M g}}{M_{t} \times M g \% M_{t}} \times 100 \\
& X_{F e}=\frac{V_{S O L} \times C_{F e}}{M_{t} \times F e \% M_{t}} \times 100 \\
& X_{S i}=\frac{V_{S O L} \times C_{S i}}{M_{t} \times S i \% M_{t}} \times 100
\end{aligned}
$$

In which: $\mathrm{X}$ represents the percentage of the element extracted; $\mathrm{Mg} \%, \mathrm{Fe} \%$, and $\mathrm{Si} \%$ are the initial element contents in the serpentinite sample; $\mathrm{M}_{\mathrm{t}}$ is the initial mass of sample used in the experiments; $\mathrm{V}_{\mathrm{SOL}}$ is the leachate solution volume after $2 \mathrm{~h}$ of reaction; $\mathrm{C}_{\mathrm{Mg}}, \mathrm{C}_{\mathrm{Fe}}$, and $\mathrm{C}_{\mathrm{Si}}$ are the concentrations of the elements in the leachate solution.

\section{Results and discussion}

\subsection{Physicochemical characterization}

MIP and $\mathrm{N}_{2}$ adsorption techniques were used to obtain the textural properties of each serpentinite rock in order to evaluate factors such as fluid permeability within particles (Das et al., 2014; Ramli et al., 2013; Zeng et al., 2014). The MIP result is obtained as pore size distribution (PSD), which is shown in the form of cumulative volume intrusion curves (Fig. 1a) and volume intrusion curves (Fig. 1b).

Cumulative volume intrusion curves (Fig. 1a) have two distinct regions: the first region is interparticle volume, and the second region is intraparticle volume. In order to evaluate the volume of fluid that was introduced into the material, cumulative intrusion volumes of the intraparticle region $\left(\mathrm{IV}_{\mathrm{I}}\right)$ have to be considered. Table 1 also shows that S-MG has an $\mathrm{IV}_{\mathrm{I}}$ average value of around $0.36 \mathrm{~mL} / \mathrm{g}$, while $\mathrm{S}-\mathrm{GO}$ has a lower value of $0.17 \mathrm{~mL} / \mathrm{g}$.

The intrusion volume differential curve (Fig. 1b) shows PSD in greater detail. Three regions can be seen in each sample. The intraparticle region is divided into a macroporous and a mesoporous region. Although both serpentinite rocks contain macro and mesopores, the mesoporous region has lower pore volume. The size of the macroporous region indicates that S-MG has greater pore volume than S-GO.

Fig. 1b also shows that for both serpentinite rocks, there is an increase in pore volume in the mesoporous region. The $\mathrm{N}_{2}$ adsorption technique was used to determine pore volume (20-500 $\mathrm{A}$ ) and BET surface area $\left(\mathrm{S}_{\mathrm{BET}}\right)$, respectively. Table 1 shows these results, in which S-GO has less pore volume in the mesoporous region. The BET surface area $\left(\mathrm{S}_{\mathrm{BET}}\right)$ for S-MG is approximately $63 \%$ greater than the $\mathrm{S}_{\mathrm{BET}}$ for S-GO.

Table 2 and Fig. 2 show the mineral phases found in both serpentinite rocks. The main phase of S-GO is lizardite $1 \mathrm{~T}(\mathrm{~L})$; the secondary phases are brucite $(B)$, clinochrysotile $(C)$, magnesite $(\mathrm{m})$ and magnetite (M). The main phases of S-MG are antigorite $(A)$ and talc

\begin{tabular}{|c|c|c|c|c|c|}
\hline \multirow[t]{2}{*}{ Materials } & \multirow{2}{*}{$\begin{array}{l}\mathrm{IV}_{\mathrm{T}} \\
(\mathrm{mL} / \mathrm{g})\end{array}$} & \multirow{2}{*}{$\begin{array}{l}\mathrm{IV}_{\mathrm{I}} \\
(\mathrm{mL} / \mathrm{g})\end{array}$} & \multirow{2}{*}{$\begin{array}{l}\mathrm{S}_{\mathrm{BET}}^{\mathrm{b}} \\
\left(\mathrm{m}^{2} / \mathrm{g}\right)\end{array}$} & \multicolumn{2}{|l|}{$\mathrm{V}_{\mathrm{p}}(\mathrm{mL} / \mathrm{g})$} \\
\hline & & & & $20-500 \AA^{b}$ & $500-40,000 \AA$ \\
\hline S-GO & 0.38 & 0.17 & 6.8 & 0.012 & 0.17 \\
\hline S-MG & 0.62 & 0.36 & 11.1 & 0.024 & 0.36 \\
\hline
\end{tabular}

Table 1

Data calculated from $\mathrm{Hg}$ intrusion and $\mathrm{N}_{2}$ adsorption curves for the materials.

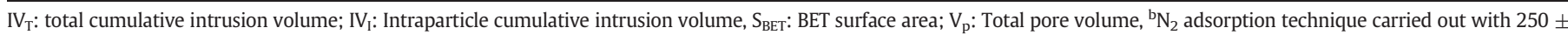
$50 \mathrm{mg}$ of material. 
Table 2

Composition of Brazilian serpentinite rock mineral phases in XDR results.

\begin{tabular}{|c|c|c|c|}
\hline Materials & Ref. code & Mineral name & Compound name \\
\hline \multirow[t]{5}{*}{ S-GO } & 00-050-1625 & $\begin{array}{l}\text { Trigonal Lizardite } \\
\text { 1T }\end{array}$ & $\begin{array}{l}\text { Aluminum Iron Magnesium } \\
\text { silicate }\end{array}$ \\
\hline & $00-027-1275$ & ClinoChrysotile & Magnesium Silicate Hydroxide \\
\hline & 01-083-0114 & Brucite & Brucite \\
\hline & 01-075-1609 & Magnetite & Magnetite \\
\hline & 01-086-2345 & Magnesite & Magnesium carbonate \\
\hline \multirow[t]{5}{*}{ S-MG } & $00-052-1573$ & $\begin{array}{l}\text { Antigorite } \\
\text { Monoclinic P }\end{array}$ & Magnesium Silicate Hydroxide \\
\hline & 00-011-0386 & Lizardite 1T & $\begin{array}{l}\text { Magnesium Aluminum Silicate } \\
\text { Hydroxide }\end{array}$ \\
\hline & 00-029-1493 & Talc $2 \mathrm{M}$ & Magnesium Silicate Hydroxide \\
\hline & 00-004-0594 & Actinolite & $\begin{array}{l}\text { Calcium Magnesium Iron Silicate } \\
\text { Hydroxide }\end{array}$ \\
\hline & 00-024-0512 & Chromite & Iron Chromium Oxide \\
\hline
\end{tabular}

$(\mathrm{T})$, and the secondary phases are lizardite $1 \mathrm{~T}(\mathrm{~L})$, actinolite (a) and chromite $(\mathrm{Ch})$. These mineralogical differences show that S-GO is derived from the hydration of dunites (olivine), however, S-MG is derived from hydration of pyroxenes (orthopyroxenes). This explains why there is brucite in S-GO, and actinolite and talc in S-MG. When the serpentinization process takes place at low temperature and pressure, serpentines can co-exist with silicon-free brucites $\left(\mathrm{Mg}(\mathrm{OH})_{2}\right)$, as shown in Eq. (4) (Evans, 2008; Frost et al., 2013; Frost and Beard, 2007). According to Styles et al. (2014); Frost and Beard (2007), pyroxene hydration processes in isothermal $\left(400-500^{\circ} \mathrm{C}\right)$ and isobaric conditions lead to the equimolar production of serpentines and talc (Eq. (5)). While temperature and pressure are important in the formation of rocks, the activity of silica $\left(a \mathrm{SiO}_{2}\right)$ is even more important. Serpentinization processes are carried out at high water activity levels $\left(a \mathrm{H}_{2} \mathrm{O}\right)$ and low silica activity levels $\left(a \mathrm{SiO}_{2}\right)$; However, when $a \mathrm{SiO}_{2}$ increases, the serpentines can form more complex minerals, as shown in Eq. (6) (Frost and Beard, 2007; Moore and Rymer, 2007; Power et al., 2013; Styles et al., 2014).

$$
\begin{aligned}
& 2 \mathrm{Mg}_{2} \mathrm{SiO}_{4}+3 \mathrm{H}_{2} \mathrm{O} \rightarrow \mathrm{Mg}_{3} \mathrm{Si}_{2} \mathrm{O}_{5}(\mathrm{OH})_{4}+\mathrm{Mg}(\mathrm{OH})_{2} \\
& 6 \mathrm{MgSiO}_{3}+3 \mathrm{H}_{2} \mathrm{O} \rightarrow \mathrm{Mg}_{3} \mathrm{Si}_{2} \mathrm{O}_{5}(\mathrm{OH})_{4}+\mathrm{Mg}_{3} \mathrm{Si}_{4} \mathrm{O}_{10}(\mathrm{OH})_{2} \\
& \mathrm{Mg}_{3} \mathrm{Si}_{2} \mathrm{O}_{5}(\mathrm{OH})_{4}+2 \mathrm{SiO}_{2} \rightarrow \mathrm{Mg}_{3} \mathrm{Si}_{4} \mathrm{O}_{10}(\mathrm{OH})_{2}+\mathrm{H}_{2} \mathrm{O}
\end{aligned}
$$

In Figs. 3 and 4, note the micrographs of S-GO and S-MG, as well as the elemental distribution of magnesium $(\mathrm{Mg})$, silicon $(\mathrm{Si})$, aluminum ( $\mathrm{Al})$, chrome $(\mathrm{Cr})$, total iron $\left(\mathrm{Fe}_{\mathrm{t}}\right)$. Fig. 3a and b, shows the elemental distribution of $\mathrm{Mg}$ and $\mathrm{Si}$, which are uniformly distributed across the micrograph of S-GO, showing the strong connection between them linked to the serpentines, in this case: lizardite 1T and clinochrysotile.
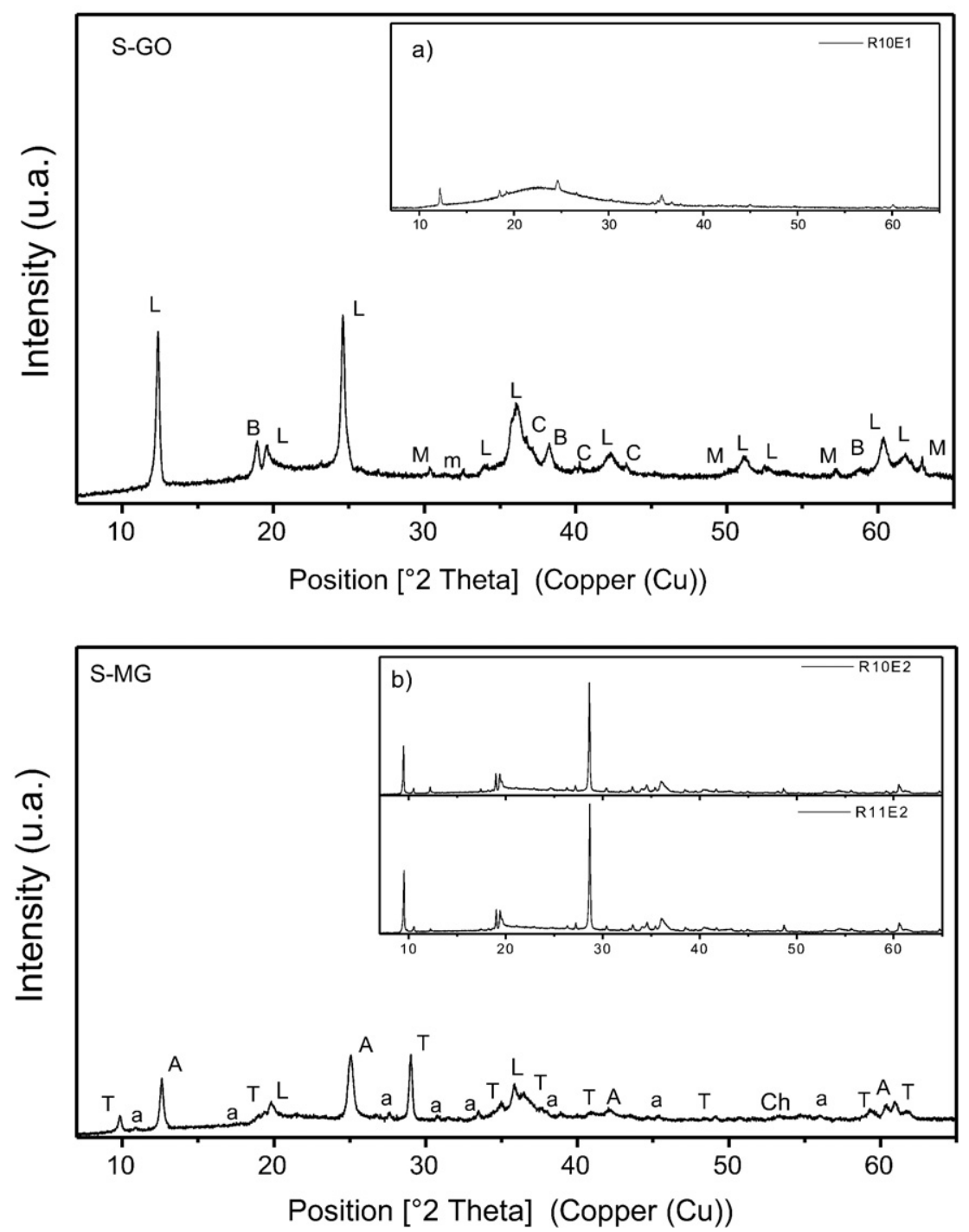

Fig. 2. X-Rays diffractograms for S-GO and S-MG “in natura". a) XRD for residue (R) after S-GO leaching, b) XRD for residues after S-MG leaching. 

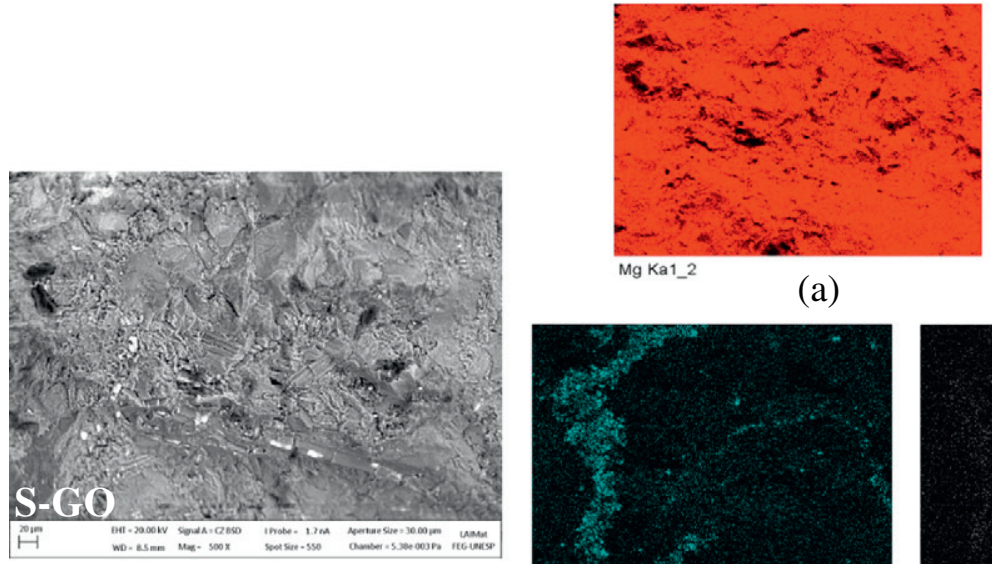

(a)

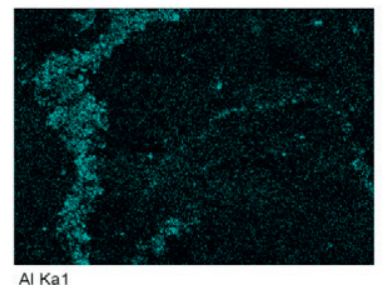

(c)

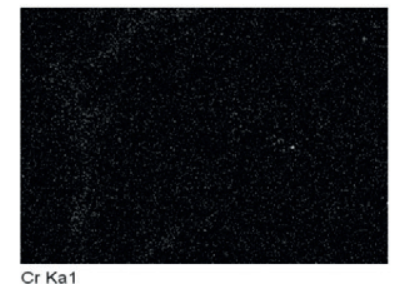

(d)

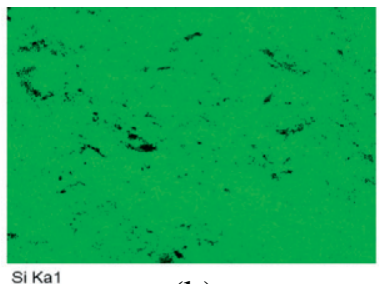

(b)

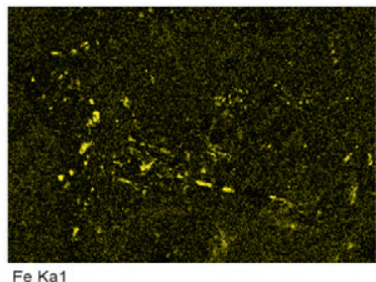

(e)

Fig. 3. Micrograph and elemental distribution of S-GO. a) magnesium ( $\mathrm{Mg}$ ), b) silicon ( $\mathrm{Si}$ ), c) aluminum ( $\mathrm{Al}$ ), d) chrome ( $\mathrm{Cr}$ ) and e) total iron (Fe).

In Fig. 3c, $\mathrm{d}$ and e, show that the elemental distribution of $\mathrm{Al}, \mathrm{Cr}$ and $\mathrm{Fe}_{\mathrm{t}}$ is in specific regions of the S-GO micrograph. Lizardites has a great affinity for cationic substitution of trivalent elements in the tetrahedral $\mathrm{Si}^{4+}$ sheet $(\mathrm{T}$ ), causing the formation of ordered and flat structures (Wicks and Whittaker, 1975). This suggests that $\mathrm{Al}^{3+}$ and $\mathrm{Cr}^{3+}$ are found in the place of $\mathrm{Si}^{4+}$ in the $\mathrm{T}$ sheets, specifically in lizardite 1T. Fig. 3e shows a few specific points at which $\mathrm{Fe}_{\mathrm{t}}$ has a high concentration due to the magnetite found in S-GO.

Fig. 4a,b and c, show the elemental distribution of magnesium ( $\mathrm{Mg}$ ), silicon ( $\mathrm{Si}$ ) and aluminum (Al) for S-MG. Note that the distribution of $\mathrm{Al}$ is uniform across the micrograph, just as $\mathrm{Mg}$ and $\mathrm{Si}$ are, though at a lesser concentration. According to the positioning of the elements, $\mathrm{Al}^{3+}$ seems to be linked to $\mathrm{Mg}^{2+}$ and $\mathrm{Si}^{4+}$, consequently silicate minerals such as antigorite, lizardite $1 \mathrm{~T}$ and/or talc might have substituted $\mathrm{Al}^{3+}$ for $\mathrm{Si}^{4+}$ in the sheet T. According to Wicks and Whittaker (1975), substitution of trivalent elements $\left(\mathrm{Al}^{3+}\right.$ and $\mathrm{Fe}^{3+}$ ) in antigorite is limited due to the curvature needed to produce octahedral sheets $(\mathrm{O})$ which are larger than tetrahedral sheets ( $\mathrm{T})$, like chrysotiles, though at a lower intensity. On the other hand, Putnis (2003); Rayner and Brown (1973) pointed out that a large number of silicates with flat structures can result from the replacement of $\mathrm{Al}^{3+}$ for $\mathrm{Si}^{4+}$ in $\mathrm{T}$ sheets. Thus talc and lizardite 1T (contained in S-MG) might have carried out the substitution. Note that $\mathrm{Cr}$ and $\mathrm{Fe}_{\mathrm{t}}$ are distributed in specific zones (Fig. $4 \mathrm{~d}$ and e). This pattern is associated with chromite $\left((\mathrm{Fe}, \mathrm{Cr})_{2} \mathrm{O}_{4}\right)$ found in S-MG.
A thermogravimetric analysis (TGA) was performed in order to characterize the thermal decomposition of each mineral contained in both serpentinite rocks. Fig. 5a and b shows TG/DTG curves for S-GO and SMG (black dotted line). A total mass loss of approximately $15.5 \%$ was observed for S-GO and $9.0 \%$ for S-MG, between 30 and $1000{ }^{\circ} \mathrm{C}$. Different DTG peaks were found (Fig. 5b), which coincided with the weight lost (Fig. 5a).

Three minerals phases were identified on DTG curve for S-GO, which were associated with specific decomposition temperatures (Fig. 5b). DTG peaks at $382{ }^{\circ} \mathrm{C}$ indicated brucite dehydroxylation. Larger DTG peaks found at $600{ }^{\circ} \mathrm{C}$ and $659{ }^{\circ} \mathrm{C}$ indicated lizardite $1 \mathrm{~T}$ and clinochrysotile dehydroxylation, respectively. Four minerals phases were identified on DTG curve for S-MG associated with specific decomposition temperatures (Fig. 5b). Larger DTG peaks indicated dehydroxylation of lizardite $1 \mathrm{~T}$ at $637{ }^{\circ} \mathrm{C}$ and antigorite at $776{ }^{\circ} \mathrm{C}$. Smaller DTG peaks indicated dehydroxylation of actinolite at $800{ }^{\circ} \mathrm{C}$ and talc at $900{ }^{\circ} \mathrm{C}$.

Chemical and elemental composition determined by XRF and ICPOES analyses is presented on Table 3. This table shows that S-MG has the highest $\mathrm{SiO}_{2}$ content. S-GO and S-MG have significantly different $\mathrm{SiO}_{2}$ contents, which can be explained by the fact that S-MG contains talc and actinolite (Fig. 2). ICP-OES analyses corroborate the difference in silicon ( $\mathrm{Si}$ ) between serpentinite samples. Table 3 also shows that there are higher levels of $\mathrm{MgO}$ in S-GO than S-MG. This is again

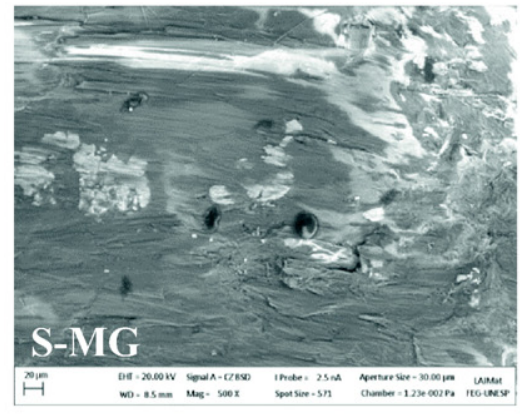

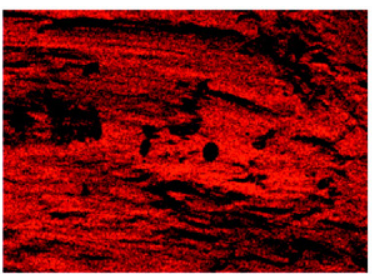

(a)

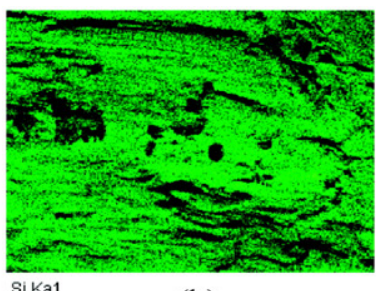

(b) (c)

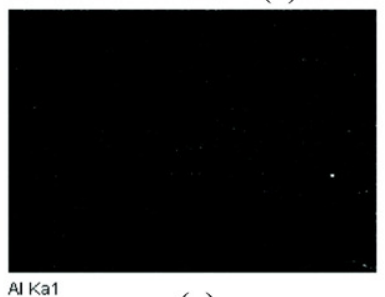

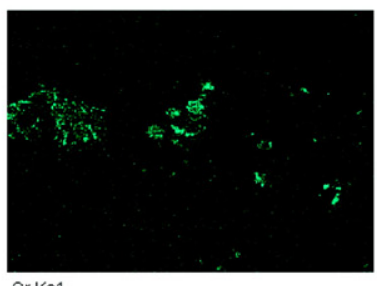

(d)

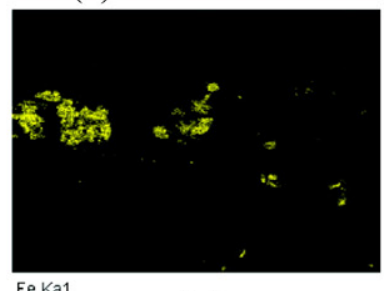

(e)

Fig. 4. Micrograph and Elemental distribution of S-MG. a) magnesium (Mg), b) silicon (Si), c) aluminum (Al), d) chrome (Cr) and e) total iron (Fe). 
a)

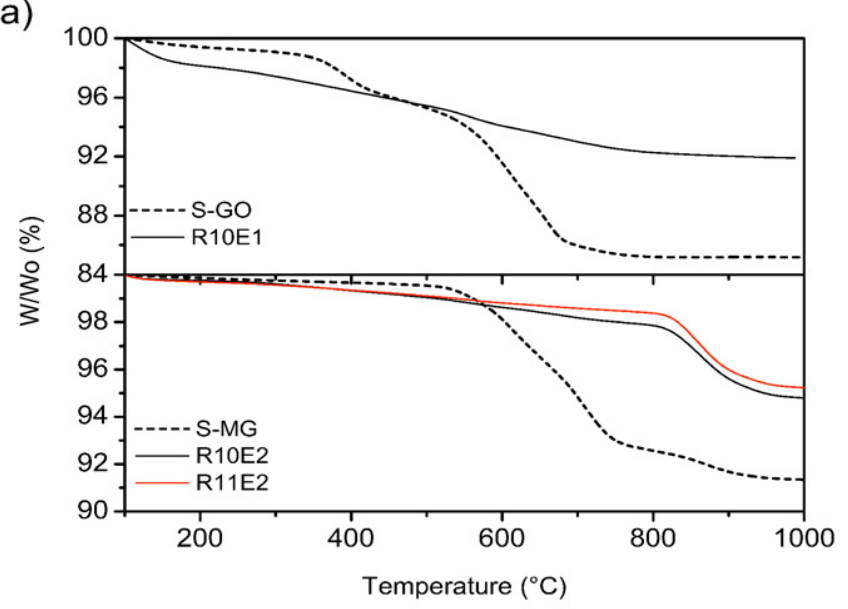

b)

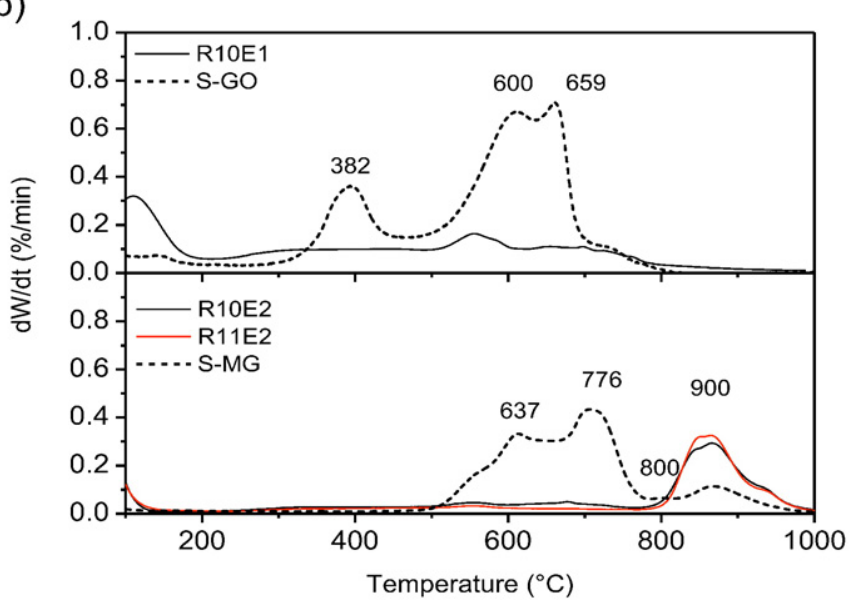

Fig. 5. Thermal decomposition of S-GO, S-MG and residues. a) TG curves, b) DTG curves.

corroborated by the Mg quantification through ICP-OES analysis; it is probably because S-GO contains brucite, which is known to be rich in Mg (Fig. 2).

\subsection{Leaching experimental tests}

Leaching experiments were performed in order to confirm the reactivity of S-GO and S-MG. Leachate solutions (L) for S-GO and S-MG were yellow and green-yellow, respectively. The solid residue (R) was

Table 3

Chemical and elemental composition in $\% \mathrm{w} / \mathrm{w}$.

\begin{tabular}{llllll}
\hline Oxides $^{\mathrm{a}}$ & $\mathrm{S}-\mathrm{GO}$ & $\mathrm{S}-\mathrm{MG}$ & Elements $^{\mathrm{a}}$ & $\mathrm{S}-\mathrm{GO}$ & S-MG \\
\hline $\mathrm{SiO}_{2}{ }^{\mathrm{c}}$ & 40.64 & 52.09 & $\mathrm{Si}^{\mathrm{c}}$ & 8.40 & 15.26 \\
$\mathrm{MgO}^{\mathrm{c}}$ & 43.33 & 30.63 & $\mathrm{Mg}^{\mathrm{c}}$ & 23.01 & 17.69 \\
$\mathrm{CaO}$ & 0.10 & 1.66 & $\mathrm{Ca}$ & $279.5^{\mathrm{d}}$ & 0.70 \\
$\mathrm{Fe}_{3} \mathrm{O}_{4}{ }^{\mathrm{c}}$ & 12.61 & 11.82 & $\mathrm{Fe}^{\mathrm{c}}$ & 4.49 & 3.66 \\
$\mathrm{~K}_{2} \mathrm{O}$ & n.d. & n.d. & $\mathrm{K}$ & $<0.01^{\mathrm{d}}$ & $<0.01^{\mathrm{d}}$ \\
$\mathrm{Na}_{2} \mathrm{O}$ & n.d. & n.d. & $\mathrm{Na}$ & $<0.02^{\mathrm{d}}$ & $<0.02^{\mathrm{d}}$ \\
$\mathrm{Al}_{2} \mathrm{O}_{3}$ & 1.17 & 2.36 & $\mathrm{Al}$ & 0.35 & 0.96 \\
$\mathrm{TiO}_{2}$ & n.d & 0.08 & $\mathrm{Ti}$ & $140.3^{\mathrm{d}}$ & $266.5^{\mathrm{d}}$ \\
$\mathrm{MnO}^{\mathrm{d} O}$ & 0.20 & 0.27 & $\mathrm{Mn}$ & $737.8^{\mathrm{d}}$ & $812.8^{\mathrm{d}}$ \\
$\mathrm{Cr}_{2} \mathrm{O}_{3}$ & 1.02 & 0.86 & $\mathrm{Cr}$ & $0.45^{\mathrm{d}}$ & 0.219 \\
$\mathrm{LOI}$ & 15.5 & 9.0 & $\mathrm{R}$ & 1.84 & 2.42 \\
\hline
\end{tabular}

a Oxides were determined by XRF analysis and elemental contents were determined by ICP-OES.

c For calculation of $\mathrm{Mg}, \mathrm{Fe}$, and Si concentrations in the leachate (L), mean values of XRF and ICP-OES were used.

b Calculated by the method proposed by Goff et al. (2000).

${ }^{\mathrm{d}} \mathrm{mg} / \mathrm{kg}$, n.d. $=$ not determined.
Table 4

$\mathrm{Mg}$, Fe, and Si extracted from S-GO and S-MG in the leaching process.

\begin{tabular}{|c|c|c|c|c|c|c|}
\hline \multirow[t]{2}{*}{ Test } & \multicolumn{3}{|c|}{ Reaction conditions } & \multicolumn{3}{|c|}{$\begin{array}{l}\text { Extraction of metals in } \\
\text { leached solutions (L) }\end{array}$} \\
\hline & $\begin{array}{l}\phi \\
(\mu \mathrm{m})\end{array}$ & $\begin{array}{l}\mathrm{C}_{\mathrm{HCl}} \\
{[\mathrm{M}]}\end{array}$ & $\begin{array}{l}\mathrm{T} \\
\left({ }^{\circ} \mathrm{C}\right)\end{array}$ & $\begin{array}{l}\mathrm{Mg} \\
\%\end{array}$ & $\begin{array}{l}\mathrm{Fe} \\
\%\end{array}$ & $\begin{array}{l}\mathrm{Si} \\
\%\end{array}$ \\
\hline T10E1 & $355-250$ & 4 & 100 & 95 & 93 & 3 \\
\hline T10E2 & $355-255$ & 4 & 100 & 34 & 60 & 2 \\
\hline T11E2 & $75-63$ & 4 & 100 & 36 & 71 & 1 \\
\hline
\end{tabular}

slightly gray for both serpentinite rocks. $\mathrm{Mg}$, Fe, and Si extractions found in the leachate (L) are shown on Table 4.

The experiments that used S-GO obtained the highest Mg and Fe extraction, of approximately $94 \pm 1 \%$ (T10E1). Nonetheless, under the same conditions, maximum $\mathrm{Mg}$ and Fe extractions from S-MG reached only $34 \%$ and $60 \%$ respectively (T10E2). In order to increase $\mathrm{Mg}$ and $\mathrm{Fe}$ extraction, rocks underwent rigorous grinding, thus the particle size was reduced from 355 to $250 \mu \mathrm{m}$ until 75-63 $\mu \mathrm{m}$. Experimental test T11E2 was then performed. As can be seen on Table 4, Mg and Fe extraction reached approximately $36 \%$ and $71 \%$, respectively.

Thermogravimetry and XRD analyses were performed on the residues (Figs. 5 and 2) in order to understand the mechanisms involved in the $\mathrm{Mg}$ and Fe extraction step and the interrelation between mineral structure and extraction performance for S-GO and S-MG. TG/DTG profiles were compared for S-GO and S-MG as well as the residues (Fig. 5), identifying if there was a partial or total reaction of each mineral contained in them. DTG peaks of the minerals that are still part of the residues can be seen on Fig. 5b, which illustrates the differences between "in natura" serpentinite rock peaks (S-GO and S-MG) and the residues $(R)$ obtained after the leaching process.

Large differences for DTG peaks were identified between all residues and both "in natura" serpentinite rocks (Fig. 5b). DTG curves for R10E1 (leaching using S-GO) showed that the characteristic peaks of lizardite $1 \mathrm{~T}\left(600^{\circ} \mathrm{C}\right)$ were less intense than S-GO peaks from this region. However, brucite $\left(382^{\circ} \mathrm{C}\right)$ was not totally extracted. The diffractogram for R10E1 (Fig. 2a) reveals that there is significant structural modification consistent with the production of amorphous silica which is formed after the bonds between octahedral and tetrahedral sheets are broken in the serpentines, in which siloxanes $(\mathrm{Si}-\mathrm{O}-\mathrm{Si}$ ) are encapsulated and precipitated as silica (Arce et al., 2017; McCutcheon et al., 2015; Sanna et al., 2013a, 2013b; Park and Fan, 2004). However, the diffractogram also shows that a large amount of the material has been transformed into amorphous silica, while non-reactive lizardite (L) and brucite (B) are still present.

Fig. 5b shows the R10E2 DTG curve for the S-MG leaching process. The characteristic peaks for lizardite $1 \mathrm{~T}\left(637{ }^{\circ} \mathrm{C}\right)$ and antigorite $\left(776{ }^{\circ} \mathrm{C}\right.$ ) were less intense than for S-MG peaks from this region. Talc was not extracted; moreover, its characteristic DTG peak $\left(900{ }^{\circ} \mathrm{C}\right)$ was more intense. The high intensity of the DTG peaks indicated that antigorite and lizardite 1T were released from the structure, leaving the talc more exposed to thermal decomposition, so that their DTG peaks was more intense. The diffractogram of R10E2 (Fig. 2b) shows that most of the antigorite and lizardite 1T were removed from the structure. However, peaks for talc (T) also increased significantly in intensity (Fig. 2b). When the R11E2 DTG curve was assessed (red line), it was nearly the same as R10E2, corroborating ICP-OES results. The leaching process using S-MG extracted 36\% of Mg. The sources of this $\mathrm{Mg}$ were the serpentines. $\mathrm{Mg}$ from talc is more difficult to extract because of its mineralogical complexity.

Talc ( $\mathrm{T}$ ) and actinolite (a) are more resistant to leaching than serpentines because of their crystalline structure. Talc is derived from the hydration of pyroxenes; in addition, the crystalline structure of both minerals is made up of tetrahedral $(\mathrm{T})$ and octahedral $(\mathrm{O})$ sheets organized in 2:1 flat layers, in which octahedral $\mathrm{Mg}^{2+}$ is encapsulated in two sheets of tetrahedral $\mathrm{Si}^{4+}$. This characteristic helps to prevent the 
bonds between the $\mathrm{O}$ - $\mathrm{T}$ sheets from breaking, making it harder to release octahedral $\mathrm{Mg}^{2+}$ (Temuujin et al., 2002).

Baba et al. (2015) and Temuujin et al. (2002) reported that $62 \%$ and $64 \%$ of talc was removed from the structure of the rock in $2 \mathrm{M} \mathrm{HCl}, 75^{\circ} \mathrm{C}$, particle size of $75 \mu \mathrm{m}$ and $4 \mathrm{M} \mathrm{H}_{2} \mathrm{SO}_{4}, 80^{\circ} \mathrm{C}$, unknown particle size, respectively. However, in our study, talc was seen to remain in the structure of S-MG (Fig. 2b). S-MG is highly resistant to leaching due to structural stability of talc given by $\mathrm{Al}^{3+}$ in the $\mathrm{T}$ sheet.

\subsection{Reactivity by physicochemical properties}

\subsubsection{Surface area-to-volume ratio $\left(S_{B E T} / V_{p}\right)$}

Gadikota et al. (2014b) claimed that reactivity is strongly affected not only by rock heterogeneity, but also by the pore structures and surface area $\left(\mathrm{S}_{\mathrm{BET}}\right)$. In chemical reactions involving solid materials, surface area-to-volume ratio is an important parameter because it employs textural properties of materials to estimate their reactivity. As pointed out by Klobes et al. (2006), porous materials with large surface area-tovolume ratios have often exhibited enhanced chemical reactivity. In addition, in many practical applications exploiting this large ratio, the size of the accessible surface is as important as the chemical composition.

Recent reports have shown that one of factors for slow kinetics in $\mathrm{CO}_{2}$ mineralization is related to the low accessible surface (surface area - to - volume ratio) of the materials (Oskierski et al., 2013; Ukwattage et al., 2015; Yuen et al., 2016). when surface area - to - volume ratio value are low, the material is less permeable to fluid, which can limit the process of diffusion into the materials (Ukwattage et al., 2015; Yuen et al., 2016).

In this manner, the larger the accessible surface is, the more reactive the material becomes, although this depends on the material's physical structure. In this study, the $S_{\mathrm{BET}} / \mathrm{V}_{\mathrm{p}}$ ratio was calculated using Eq. (7), in which $\mathrm{S}_{\mathrm{BET}}$ is the BET surface area and $\mathrm{V}_{\mathrm{p}}$ is the total pore intraparticle volume.

$r=\frac{S_{B E T}}{V_{p}}$

\subsubsection{Metals - silicon ratio $(\Sigma(\mathrm{Mg}, \mathrm{Ca}) / \mathrm{Si})$}

The reactivity also will depend on the mineralogical complexity which is linked to silica activity $\left(\mathrm{aSiO}_{2}\right)$. Beyond of temperature, pressure, water activity $\left(\mathrm{aH}_{2} \mathrm{O}\right)$ and oxygen fugacity $\left(\mathrm{fO}_{2}\right)$, the silica activity $\left(\mathrm{aSiO}_{2}\right)$ is one of the most important parameters used in the classification of igneous rocks (Evans, 2008; Frost and Beard, 2007; Putnis, 2003).

As earlier mentioned, several minerals can co-exist with the serpentines, and mineralogical complexity is proportional to silica activity $\left(\mathrm{aSiO}_{2}\right)$ (Evans, 2008; Faust and Fahey, 1962; Frost et al., 2013). According to Oskierski et al. (2013), low $\mathrm{MgO} / \mathrm{SiO}_{2}$ ratios are related to silicified and weathered serpentinites. The silicification stage is accompanied by a gain in $\mathrm{SiO}_{2}$ and losses of $\mathrm{MgO}$ and $\mathrm{CaO}$, while early stages of weathering normally cause pores to develop (Oskierski et al., 2013).

Some authors state that mineralogical complexity is inversely proportional to reactivity. For example, minerals hydrated from dunites (olivine $\mathrm{Mg}_{2} \mathrm{SiO}_{4}$ ) have lower $\mathrm{Si}$ content in the structure than minerals hydrated from pyroxenes $\left(\mathrm{MgSiO}_{3}\right.$ and $\left.(\mathrm{Mg}, \mathrm{Ca}) \mathrm{SiO}_{3}\right)$ (Styles et al., 2014). Thus, serpentinite rocks derived from dunites are more reactive for indirect mineral carbonation (Lavikko and Eklund, 2016; Styles et al., 2014). Assima et al. (2013) also reported that serpentinite rocks with higher $\mathrm{Mg} / \mathrm{Si}$ molar ratio are more efficient for atmospheric $\mathrm{CO}_{2}$ capture.

The reactivity based on mineralogical complexity should be assessed, using Mg, Ca, and Si ratios. Thus, due to the large mineral complexity of rocks, a mass ratio of these elements was considered for this
Table 5

$\Sigma(\mathrm{Mg}, \mathrm{Ca}) / \mathrm{Si}$ and $\mathrm{S}_{\mathrm{BET}} / \mathrm{Vp}$ ratios for serpentinite rocks.

\begin{tabular}{lll}
\hline Parameters & S-GO & S-MG \\
\hline $\mathrm{S}_{\mathrm{BET}} / \mathrm{V}_{\mathrm{p}}$ & 36 & 29 \\
$\Sigma(\mathrm{Mg}, \mathrm{Ca}) / \mathrm{Si}$ & 2.64 & 1.20 \\
\hline
\end{tabular}

study, as shown in Eq. (8).

$r=\frac{\sum(M g, C a)}{S i}$

\subsubsection{Reactivity of serpentinine rocks}

Elemental composition, MIP, and $\mathrm{N}_{2}$ adsorption results from Tables 1, 2 and 3 were used in Eqs. (7) and (8) to determine $S_{B E T} / V_{p}$ and $\Sigma(\mathrm{Mg}, \mathrm{Ca}) / \mathrm{Si}$ ratios, which are shown on Table 5 . Although S-GO and S-MG have similar $\mathrm{R}_{\mathrm{CO} 2}$ (Table 3$), \Sigma(\mathrm{Mg}, \mathrm{Ca}) / \mathrm{Si}$ results suggest that $\mathrm{S}-\mathrm{GO}$ is a less complex rock because it has a higher value than S-MG.

An increase in $\Sigma(\mathrm{Mg}, \mathrm{Ca}) / \mathrm{Si}$ ratio, is only possible when a serpentinite rocks contains $\mathrm{Si}$-free magnesium and/or minerals with low levels of Si. S-GO had a high level of this ratio due to the presence of brucite $\left(\mathrm{Mg}(\mathrm{OH})_{2}\right)$. The structure of S-GO is made up of $6.1 \%$ brucite (Arce et al., 2017). Although this quantity isn't very high, this mineralogical characteristic makes S-GO more efficient at leaching than S-MG.

In contrast, while $S-G O$ has a lower BET surface area $\left(\mathrm{S}_{\mathrm{BET}}\right)$ than $\mathrm{S}$ $M G$, the $S_{\mathrm{BET}} / \mathrm{V}_{\mathrm{p}}$ results indicated that S-GO has a larger accessible surface for reaction in leaching. A greater value would indicate more permeability at the beginning of the reaction to any fluid within the material. This is interesting because it could explain the high extraction rate reported by Arce et al. (2017), in which $88 \pm 2 \%$ of $\mathrm{Mg}$ and Fe were extracted from S-GO in the first $30 \mathrm{~min}$ of the reaction.

Both mineralogical and textural characteristics of S-GO indicate that it is more reactive. The $S_{\mathrm{BET}} / \mathrm{V}_{\mathrm{p}}$ ratio shows the behavior of the diffusion processes and the $\Sigma(\mathrm{Mg}, \mathrm{Ca}) / \mathrm{Si}$ ratio indicates the mineralogical complexity of the serpentinite rocks. Nonetheless, there are other parameters such as chemistry and crystal structure that should be taken into consideration.

Considering both serpentinite rocks, it can be verified that S-GO is twice as reactive as S-MG. S-MG is more stable because of the high level of $\mathrm{Al}^{3+}$ in the $\mathrm{T}$ sheets of talc. It also is more limited by diffusion between silica hydrated layers formed on the leaching, and then, due to greater mineralogical complexity. Moreover, mechanical activation did not have a significant effect in this particular case. Therefore, more intensive mechanical activation and/or more active acids could be applied to S-MG in order to increase leaching efficiency, though this would make the process more costly. On the other hand, due to the chemical characteristics of S-GO, more intensive mechanic activation was not needed. This will reduce the energy consumption on the pretreatment method, and less active acid can be used.

\subsection{Comparison of results obtained with published data}

Based on results obtained, a comparison was made with data from previously published studies on Mg extraction efficiency, physicochemical properties, and reaction conditions, as shown on Table 6 and Fig. 6 .

Different results from several published studies could be explained by $\Sigma(\mathrm{Mg}, \mathrm{Ca}) / \mathrm{Si}$ ratio values, as showed on Table 6 . Several studies have used serpentinite (Daval et al., 2013; Park and Fan, 2004; Styles et al., 2014; Teir et al., 2007b; Wang and Maroto-Valer, 2011b), nonetheless, $\mathrm{Mg}$ extraction in function of $\Sigma(\mathrm{Mg}, \mathrm{Ca}) / \mathrm{Si}$ ratio varied a lot, as shown in Fig. 6 (black point). This behavior may have been caused by polymorphism and the crystal structure of serpentinites (chrysotile, antigorite, and lizardite).

When other silicate rocks were used, such as the pyroxenes and amphiboles shown on Table 6 (Meyer et al., 2014; Sanna et al., 2014a, 
Table 6

Published results for the leaching process in indirect mineral carbonation.

\begin{tabular}{|c|c|c|c|c|c|c|c|c|c|c|c|c|}
\hline \multirow[t]{2}{*}{ Silicate rocks } & \multirow[t]{2}{*}{ Minerals } & \multirow{2}{*}{$\begin{array}{l}\% \mathrm{Mg} \\
\text { Extracted }\end{array}$} & \multirow[t]{2}{*}{ Acid } & \multirow[t]{2}{*}{ Conditions } & \multicolumn{5}{|c|}{ Characteristics } & \multicolumn{2}{|l|}{ Parameters } & \multirow[t]{2}{*}{ References } \\
\hline & & & & & $\begin{array}{l}\mathrm{BET} \\
\mathrm{m}^{2} / \mathrm{g}\end{array}$ & $\begin{array}{l}\text { PS } \\
\mu \mathrm{m}\end{array}$ & $\begin{array}{l}\mathrm{Mg} \\
\%\end{array}$ & $\begin{array}{l}\mathrm{Ca} \\
\%\end{array}$ & $\begin{array}{l}\mathrm{Si} \\
\%\end{array}$ & $\Sigma(\mathrm{Mg}, \mathrm{Ca}) / \mathrm{Si}$ & $\mathrm{R}_{\mathrm{CO} 2}$ & \\
\hline [1] Pyroxenes ${ }^{a}$ & $\begin{array}{l}\text { Orthopyroxenes } \\
\text { Plagioclases }\end{array}$ & 5 & $\mathrm{HCl}$ & $2 \mathrm{M}, 70{ }^{\circ} \mathrm{C}, 8 \mathrm{~h}$ & n.r. & 283 & 16.3 & 0.4 & 25.7 & 0.65 & 3.33 & (Meyer et al., 2014) \\
\hline [2] Serpentinite & Lizardite & 9 & $\mathrm{HCl}$ & $1 \mathrm{M}, 90{ }^{\circ} \mathrm{C}, 2 \mathrm{~h}$ & 7.2 & $500-800$ & 24.5 & n.r. & 19.7 & 1.24 & 2.26 & (Daval et al., 2013) \\
\hline [3] Olivine & $\begin{array}{l}\text { Forsterite } \\
\text { lizardite }\end{array}$ & 98 & $\mathrm{HCl}$ & $1 \mathrm{M}, 100{ }^{\circ} \mathrm{C}, 6 \mathrm{~h}$ & n.r. & $<56$ & 28.17 & 0.29 & 19.96 & 1.43 & 1.95 & (Hemmati et al., 2014b) \\
\hline [4] Serpentinite & Antigorite & 40 & $\mathrm{HCl}$ & $1 \mathrm{M}, 70^{\circ} \mathrm{C}, 5 \mathrm{~h}$ & 4.2 & 37 & 27,1 & n.r. & 20.1 & 1.35 & 2.04 & (Park and Fan, 2004) \\
\hline [5] Serpentinite ${ }^{b}$ & $\begin{array}{l}\text { Chrysotile } \\
\text { antigorite } \\
\text { lizardite }\end{array}$ & $\begin{array}{l}100 \\
80\end{array}$ & $\mathrm{HCl}$ & $\begin{array}{l}2 \mathrm{M}, 70^{\circ} \mathrm{C}, 2 \mathrm{~h} \\
2 \mathrm{M}, 70^{\circ} \mathrm{C}, 2 \mathrm{~h}\end{array}$ & $\begin{array}{l}27.9 \\
\text { n.r. }\end{array}$ & $\begin{array}{l}75-150 \\
300-500\end{array}$ & 21.83 & 0.34 & 11.59 & 1.61 & 2.51 & (Teir et al., 2007a) \\
\hline [6] Amphibole & $\begin{array}{l}\text { Actinolite } \\
\text { prehnite } \\
\text { clinochlore }\end{array}$ & 30 & $\mathrm{NH}_{4} \mathrm{HSO}_{4}$ & $1.4 \mathrm{M}, 100^{\circ} \mathrm{C}, 3 \mathrm{~h}$ & n.r & $75-150$ & 7.3 & 10.6 & 21.5 & 0.84 & 4.02 & (Sanna et al., 2014a) \\
\hline [7] Pyroxenes & $\begin{array}{l}\text { Diopsite } \\
\text { forsterite } \\
\text { enstatite }\end{array}$ & 30 & $\mathrm{NH}_{4} \mathrm{HSO}_{4}$ & $1.4 \mathrm{M}, 100{ }^{\circ} \mathrm{C}, 3 \mathrm{~h}$ & n.r & $75-150$ & 12.4 & 12.3 & 23.0 & 1.07 & 2.78 & \\
\hline [8] Serpentinite & $\begin{array}{l}\text { Antigorite } \\
\text { forsterite }\end{array}$ & 98 & $\mathrm{NH}_{4} \mathrm{HSO}_{4}$ & $1.4 \mathrm{M}, 100^{\circ} \mathrm{C}, 3 \mathrm{~h}$ & n.r. & $75-150$ & 24.28 & 0.07 & 17.81 & 1.37 & 2.28 & $\begin{array}{l}\text { (Wang and Maroto-Valer, } \\
\text { 2011a) }\end{array}$ \\
\hline [9] Olivine & $\begin{array}{l}\text { Forsterite } \\
\text { enstatite }\end{array}$ & 78 & $\mathrm{NH}_{4} \mathrm{HSO}_{4}$ & $1.4 \mathrm{M}, 100^{\circ} \mathrm{C}, 3 \mathrm{~h}$ & n.r. & $75-150$ & 29 & 0.3 & 19.6 & 1.50 & 1.89 & (Sanna et al., 2014a) \\
\hline [10] Serpentinite & $\begin{array}{l}\text { Antigorite } \\
\text { lizardite } \\
\text { verculite }\end{array}$ & 20 & $\mathrm{H}_{2} \mathrm{SO}_{4}$ & $1 \mathrm{M}, 50^{\circ} \mathrm{C}, 2 \mathrm{~h}$ & n.r. & 90 & 23.7 & 0.3 & 17.57 & 1.36 & 2.31 & $\begin{array}{l}\text { (Van Essendelft and Schobert, } \\
\text { 2009) }\end{array}$ \\
\hline [11] Serpentinite & $\begin{array}{l}\text { Antigorite } \\
\text { lizardite } \\
\text { verculite }\end{array}$ & 70 & $\mathrm{H}_{2} \mathrm{SO}_{4}$ & $5 \mathrm{M}, 75^{\circ} \mathrm{C}, 2 \mathrm{~h}$ & n.r. & 38 & 23.7 & 0.3 & 17.57 & 1.36 & 2.31 & \\
\hline
\end{tabular}

n.r. $=$ not reported

a Elemental composition was not reported, therefore values of Mg, Ca, and Si for orthopyroxenes were obtained from the Ocean Discovery Program website http://www-odp.tamu.edu/ publications/176_sr/chap_04/c4_t7.htm\#974985.

b $\mathrm{Mg}, \mathrm{Ca}$, and Si values are the average between XRF and ICP-OES data, provided by the author.

2014b), lower Mg extraction efficiencies were found, even when using more active acids, such as $\mathrm{NH}_{4} \mathrm{HSO}_{4}$ (Table 6 and Fig. 6). This can be explained by the fact that these rocks have lower $\Sigma(\mathrm{Mg}, \mathrm{Ca}) / \mathrm{Si}$ ratio values than serpentinites. As affirmed by Lavikko and Eklund (2016), serpentinites derived from dunites are more reactive than serpentinites derived from pyroxenes. They also conclude that amphiboles and pyroxenes cannot be recommended as CCSM-appropriate materials.

As shown on Table 6, authors that have worked with serpentinite (lizardite) and pyroxenes using $\mathrm{HCl}$ solutions in similar conditions (Daval et al., 2013; Meyer et al., 2014) regard larger particle sizes (500-800 $\mu \mathrm{m}$ and $283 \mu \mathrm{m}$, respectively). Consequently, they had lower $\mathrm{Mg}$ extraction values. Note that their rocks had low $\Sigma(\mathrm{Mg}, \mathrm{Ca}) / \mathrm{Si}$ values (Table 6), so they should either have used a more concentrated acid, or applied a more intense mechanical activation in order to increase $\mathrm{Mg}$ extraction efficiency, as it was accomplished by Van

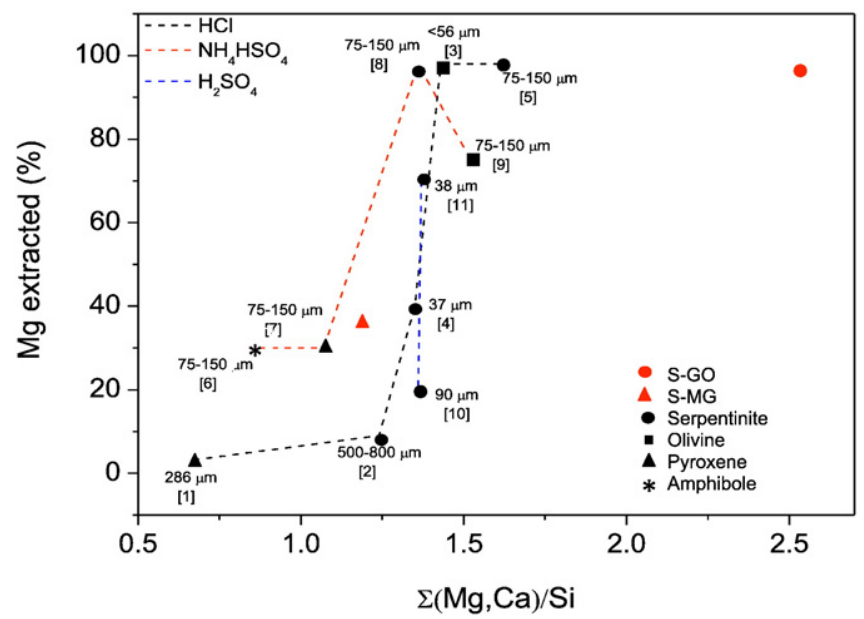

Fig. 6. $\mathrm{Mg}$ extraction vs. $\Sigma(\mathrm{Mg}, \mathrm{Ca}) / \mathrm{Si}$ from literature results. [] refers to authors on Table 6.
Essendelft and Schobert (2009). The lizardite used by Daval et al. (2013) had low Mg extraction. This may have been because of the structural stability offered by the flat layers due to cationic substitution of trivalent elements. However, the $\mathrm{Al}^{3+}$ level reported by Daval et al. (2013) was $0.88 \%$ in the form $\mathrm{Al}_{2} \mathrm{O}_{3}$. According to Lacinska et al. (2016), lizardite $1 \mathrm{~T}$ with low $\mathrm{Al}_{2} \mathrm{O}_{3}$ (1\%) levels, lead to higher $\mathrm{Mg}$ extraction than lizardite 1T with high $\mathrm{Al}_{2} \mathrm{O}_{3}$ levels (2.36\%). Since the lizardite used by Daval et al. (2013) had low $\mathrm{Al}_{2} \mathrm{O}_{3}$ levels, the low extraction could be caused by the large particle size of the material used (500$800 \mu \mathrm{m})$. When using rocks with $\Sigma(\mathrm{Mg}, \mathrm{Ca}) /$ Si ratio values lower than 1.28 (ideal serpentinite), they should be mechanically activated more. Therefore, particle size definition is based on physicochemical properties of the material.

As observed on Fig. 6, when using $\mathrm{NH}_{4} \mathrm{HSO}_{4}$, a serpentinite with 1.37 of $\Sigma(\mathrm{Mg}, \mathrm{Ca}) /$ Si ratio (Wang and Maroto-Valer, 2011a) was more efficient than an olivine with 1.50 of $\Sigma(\mathrm{Mg}, \mathrm{Ca}) / \mathrm{Si}$ ratio (Sanna et al., $2014 b$ ) although the same reaction conditions were employed. This difference can be explained by $\mathrm{S}_{\mathrm{BET}} / \mathrm{V}_{\mathrm{p}}$ ratio values. Olivine has probably a low $S_{\mathrm{BET}} / V_{\mathrm{p}}$ value, suggesting that there is less accessible surface than serpentinite, hence limiting its reactivity. However, this parameter for olivine could not be determined since the authors have not provided $\mathrm{S}_{\mathrm{BET}}$ and $\mathrm{V}_{\mathrm{p}}$ data. Future works concerning to reactivity of other silicate rocks should be studied to provide more data. For both olivines on Table 6 , particle size reduction to $<56 \mu \mathrm{m}$ was enough to increase olivine reactivity (Hemmati et al., 2014a).

In this study, when mechanical activation was applied to S-MG to reduce its size to $63-75 \mu \mathrm{m}$, it did not increase reactivity because of its mineralogical complexity and crystal structure.

\section{Conclusions}

This study investigated the performance of leaching processes for use in $\mathrm{pH}$ swing mineral carbonation. Two different Brazilian serpentinite rocks were employed. This study also explored the 
reactivity and limitations of each of them in order to evaluate $\mathrm{Mg}$ and Fe extraction.

Two parameters were used: the $S_{\mathrm{BET}} / \mathrm{V}_{\mathrm{p}}$ ratio and the $\Sigma(\mathrm{Mg}, \mathrm{Ca}) / \mathrm{Si}$ ratio. They are suitable to measure the resistance of these Brazilian serpentinite rocks to leaching considered the most critical step in indirect mineral carbonation. Both serpentinite rocks evaluated in this study have a reasonable $\mathrm{R}_{\mathrm{CO} 2}$. However, S-MG is less reactive than S-GO, due to lower values of $\mathrm{S}_{\mathrm{BET}} / \mathrm{V}_{\mathrm{p}}$ and $\Sigma(\mathrm{Mg}, \mathrm{Ca}) / \mathrm{Si}$ ratios than $\mathrm{S}$-GO.

Results suggest that physicochemical properties determined the efficiency of $\mathrm{Mg}$ and Fe extraction in the leaching step, for both serpentinite rocks. S-GO and S-MG contained $8.4 \%$ and $15.3 \%$ Si into their structure; consequently, $\Sigma(\mathrm{Mg}, \mathrm{Ca}) / \mathrm{Si}$ ratio values were 2.64 and 1.2 , respectively. Nonetheless, $\mathrm{S}_{\mathrm{BET}} / \mathrm{V}_{\mathrm{p}}$ results indicate that S-GO has a larger accessible surface than S-MG for the leaching process. Consequently, Mg and Fe extraction from S-GO were $60 \%$ and $40 \%$ better than from S-MG, respectively.

Therefore, S-MG was limited not only by the low $\mathrm{S}_{\mathrm{BET}} / \mathrm{V}_{\mathrm{p}}$ and $\Sigma(\mathrm{Mg}, \mathrm{Ca}) / \mathrm{Si}$ ratio values but also due to the crystal structure of the talc found in SMG. The higher mineralogical complexity of S-MG reduced Mg and Fe extraction. It must be mentioned that XRD and TG/DTG analyses pointed out that $\mathrm{Mg}$ from talc was not leached even at high temperatures $\left(100{ }^{\circ} \mathrm{C}\right)$, a high acid concentration $(4 \mathrm{M} \mathrm{HCl})$, and small particle size ( $\left.75-63 \mu \mathrm{m}\right)$. Talc was more stable that in other published studies because $\mathrm{Al}^{3+}$ is found in the structure rather than tetrahedral Si. Therefore, even when S-MG was more finely ground, the $\mathrm{Mg}$ was not extracted from the talc.

On the other hand, S-GO was less complex and therefore more reactive, improving Mg and Fe extraction. Mg extraction from lizardite 1T improved, even at large particle sizes (355-250 $\mu \mathrm{m})$. This is interesting since lizardite 1T was defined as the most complex within the serpentinite group. In many cases, Mg leaching from lizardite 1T was much lower than chrysotile and antigorite (Daval et al., 2013; Sanna et al., 2013b).

For indirect mineral carbonation, low levels of trivalent elements, especially $\mathrm{Al}^{3+}$ in the tetrahedral sheets, higher $\mathrm{S}_{\mathrm{BET}} / \mathrm{V}_{\mathrm{p}}$ and $\Sigma(\mathrm{Mg}, \mathrm{Ca}) / \mathrm{Si}$ values will be a determining factors in the use of the silicate rocks.

In the leaching process, the $\mathrm{S}_{\mathrm{BET}} / \mathrm{V}_{\mathrm{p}}$ ratio is an indicator of the behavior of diffusion processes, just as the $\Sigma(\mathrm{Mg}$,Ca)/Si ratio and crystal structure show the mineralogical complexity. Note that these parameters are not able to predict the extraction efficiency by themselves; however, using them provides important information that can direct the selection of material in future studies.

\section{Acknowledgements}

The authors are grateful to FAPESP for post-doctoral project number 2013/21244-5 and regular research project number 2011/19920-7 and CNPq for project number 150894/2014-7, which supported this study. The authors would also like to thank their laboratory coworkers: LCP/INPE in Cachoeira Paulista, Dr. José Augusto Jorge Rodrigues; LAS/INPE in São José dos Campos, Dr. João Paulo Barros Machado; LAI/FEG/UNESP, Dr. Luis Rogério de Oliveira Hein; LDF/CTA/ITA, Dr. Rosa Maria Rocha. In addition, the authors acknowledge the companies which provided the materials for the study: Mineração Associada (SAMA S.A.), Mineradora Pedras Congonhas Nova Lima.

\section{Appendix A. Appendix}

a)

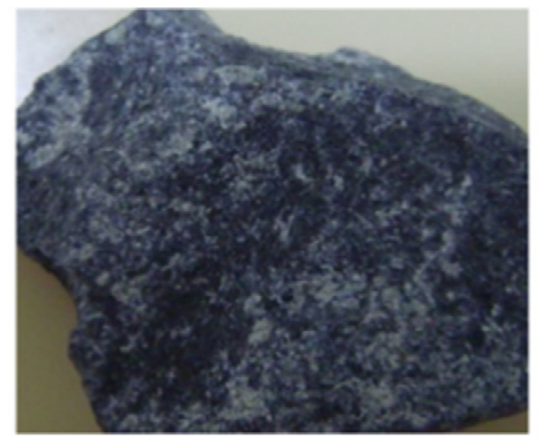

b)

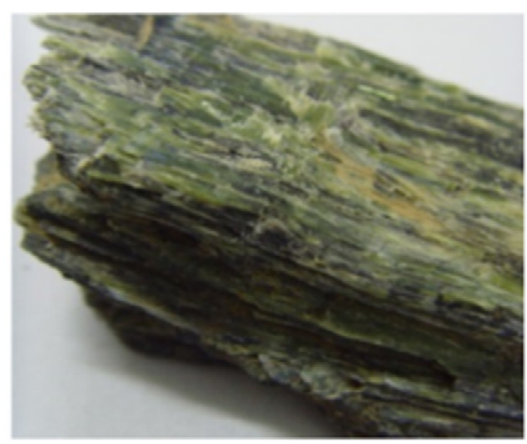

Fig. A1. Serpentinite rocks "in natura": (a) S-GO, (b) S-MG.

\section{References}

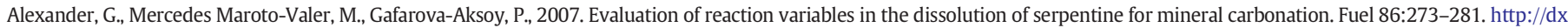
doi.org/10.1016/j.fuel.2006.04.034.

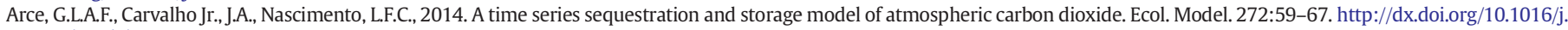
ecolmodel.2013.09.006

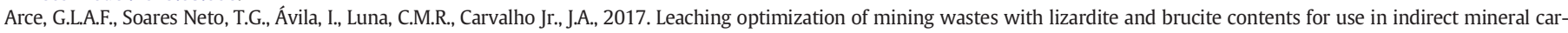
bonation through the pH swing method. J. Clean. Prod. 141:1324-1336. http://dx.doi.org/10.1016/j.jclepro.2016.09.204.

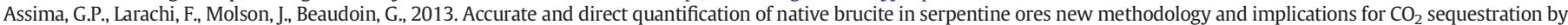
mining residues. Thermochim. Acta 566:281-291. http://dx.doi.org/10.1016/j.tca.2013.06.006.

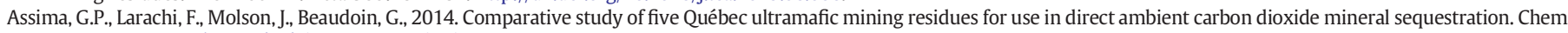
Eng. J. 245:56-64. http://dx.doi.org/10.1016/j.cej.2014.02.010.

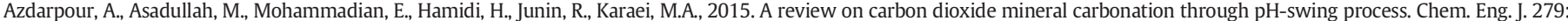
615-630. http://dx.doi.org/10.1016/j.cej.2015.05.064.

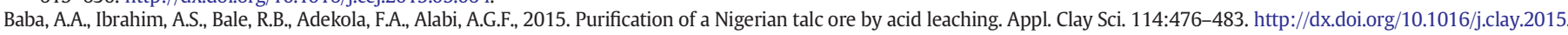
06.031.

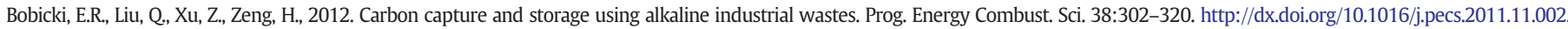

Bobicki, E.R., Liu, Q., Xu, Z., 2015. Mineral carbon storage in pre-treated ultramafic ores. Miner. Eng. 70:43-54. http://dx.doi.org/10.1016/j.mineng.2014.08.009.

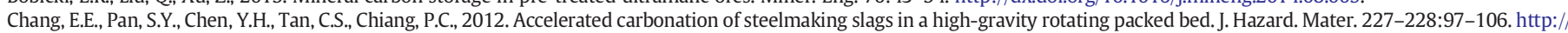
dx.doi.org/10.1016/j.jhazmat.2012.05.021. 


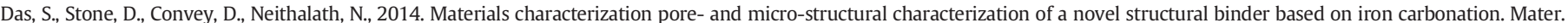
Charact. 98:168-179. http://dx.doi.org/10.1016/j.matchar.2014.10.025.

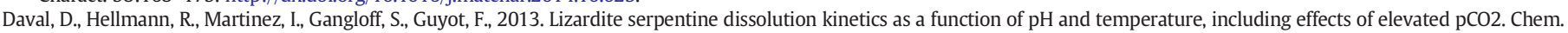
Geol. 351:245-256. http://dx.doi.org/10.1016/j.chemgeo.2013.05.020.

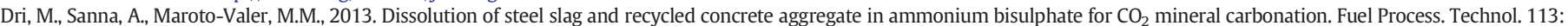
114-122. http://dx.doi.org/10.1016/j.fuproc.2013.03.034.

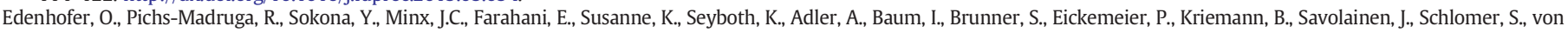
Stechow, C., Zwickel, T., 2014. IPCC 2014: climate change 2014: mitigation of climate change. Working Group III Contribution to the Fifth Assessment Report of the Intergovernmental Panel on Climate Change http://dx.doi.org/10.1017/CBO9781107415416.

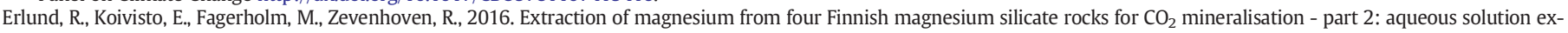
traction. Hydrometallurgy http://dx.doi.org/10.1016/j.hydromet.2016.07.005.

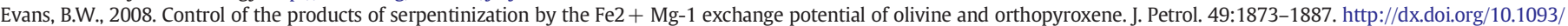
petrology/egn050.

Faust, G., Fahey, J., 1962. The Serpentine-Group Minerals: Geological Survey Professional Paper 384-A.

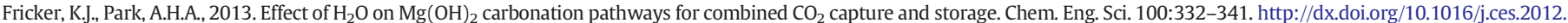
12.027.

Frost, R.B., Beard, J.S., 2007. On silica activity and serpentinization. J. Petrol. 48:1351-1368. http://dx.doi.org/10.1093/petrology/egm021.

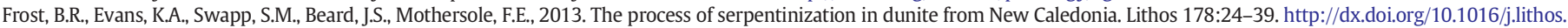
2013.02.002.

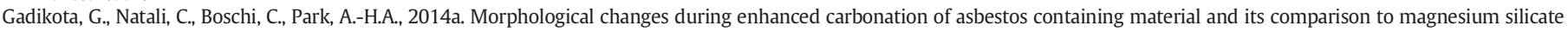
minerals. J. Hazard. Mater. 264:42-52. http://dx.doi.org/10.1016/j.jhazmat.2013.09.068.

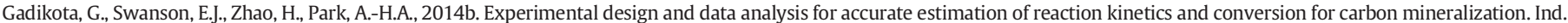
Eng. Chem. Res. 53:6664-6676. http://dx.doi.org/10.1021/ie500393h.

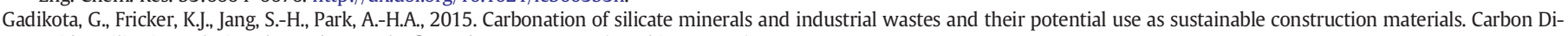
oxide Utilisation: Closing the Carbon Cycle, first ed. :pp. 115-137 (Washington DC). 10.1016/B978-0-444-62746-9.00008-6.

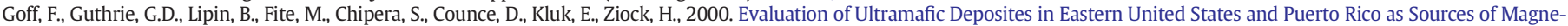
sium for Carbon Dioxide Sequestration (New Mexico).

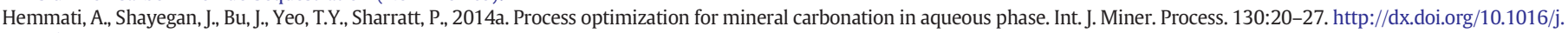
minpro.2014.05.007.

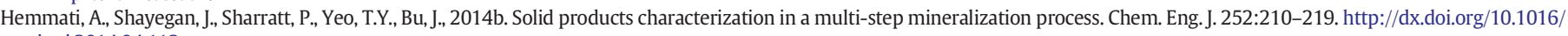
j.cej.2014.04.112.

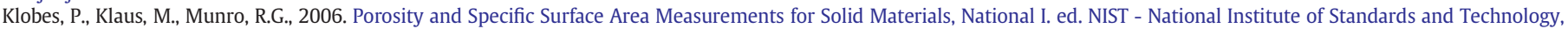
Washington.

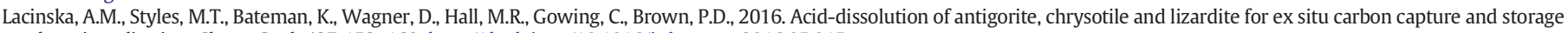
by mineralisation. Chem. Geol. 437:153-169. http://dx.doi.org/10.1016/j.chemgeo.2016.05.015.

Lackner, K.S., Wendt, C.H., Butt, D.P., Joyce, E.L., Sharp, D.H., 1995. Carbon dioxide disposal in carbonate minerals. Energy $20,1153-1170$.

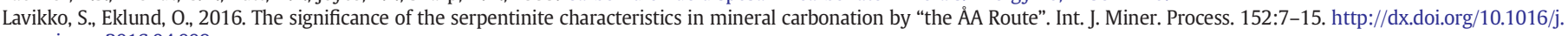
minpro.2016.04.009.

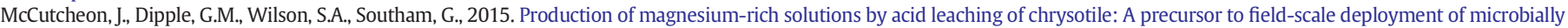
enabled carbonate mineral precipitation. Chem. Geol. 413, 119-131.

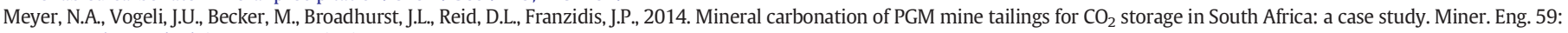
45-51. http://dx.doi.org/10.1016/j.mineng.2013.10.014.

Moore, D.E., Rymer, M.J., 2007. Talc-bearing serpentinite and the creeping section of the San Andreas fault. Nature 448:795-797. http://dx.doi.org/10.1038/nature06064.

Olajire, A.A., 2013. A review of mineral carbonation technology in sequestration of $\mathrm{CO}_{2}$. J. Pet. Sci. Eng. 109:364-392. http://dx.doi.org/10.1016/j.petrol.2013.03.013.

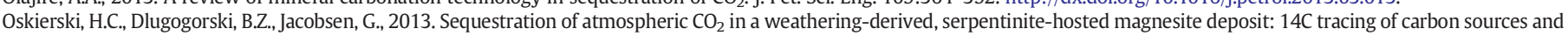
age constraints for a refined genetic model. Geochim. Cosmochim. Acta 122:226-246. http://dx.doi.org/10.1016/j.gca.2013.08.029.

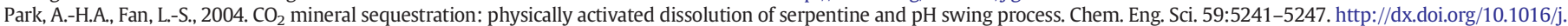
ces.2004.09.008

Power, I.M., Wilson, S.A., Dipple, G.M., 2013. Serpentinite carbonation for $\mathrm{CO}_{2}$ sequestration. Elements 9:115-121. http://dx.doi.org/10.2113/gselements.9.2.115

Putnis, A., 2003. Introduction to Mineral Science. Cambridge University Press, United States of America.

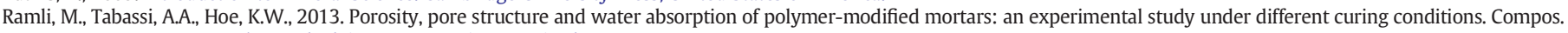
Part B Eng 55:221-233. http://dx.doi.org/10.1016/j.compositesb.2013.06.022.

Rayner, J.H., Brown, G., 1973. The crystal structure of talc. Clay Clay Miner. 21:103-114. http://dx.doi.org/10.1016/j.bbapap.2011.09.006.

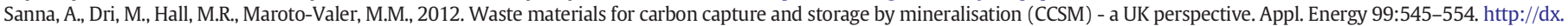
doi.org/10.1016/j.apenergy.2012.06.049.

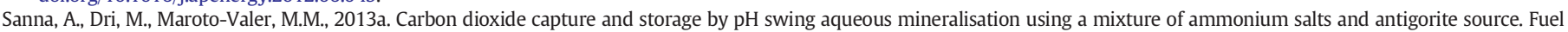
114:153-161. http://dx.doi.org/10.1016/j.fuel.2012.08.014.

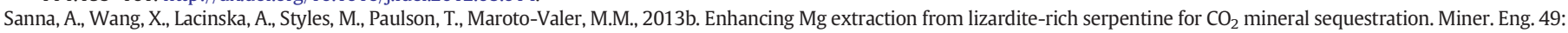
135-144. http://dx.doi.org/10.1016/j.mineng.2013.05.018.

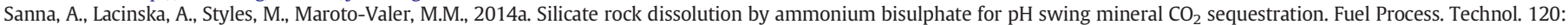
128-135. http://dx.doi.org/10.1016/j.fuproc.2013.12.012.

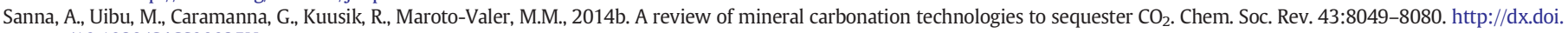
org/10.1039/C4CS00035H.

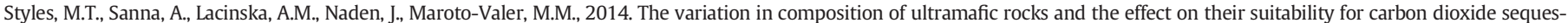
tration by mineralization following acid leaching. Greenh. Gases. Sci. Technol. 4:1-12. http://dx.doi.org/10.1002/ghg.1405.

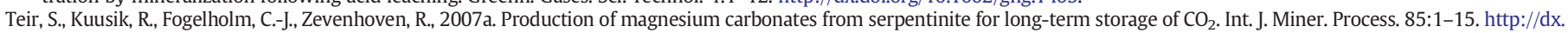
doi.org/10.1016/j.minpro.2007.08.007.

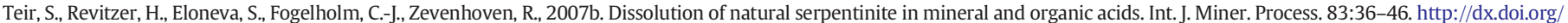
10.1016/j.minpro.2007.04.001.

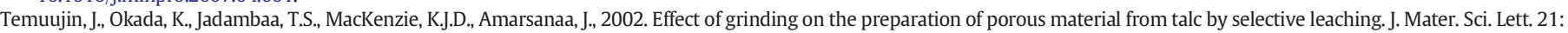
1607-1609. http://dx.doi.org/10.1023/A:1020373617167.

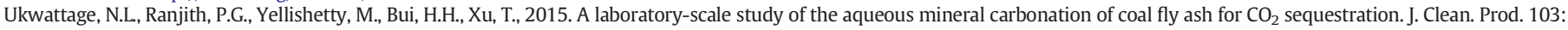
665-674. http://dx.doi.org/10.1016/j.jclepro.2014.03.005.

Van Essendelft, D.T., Schobert, H.H., 2009. Kinetics of acid digestion of serpentine with concurrent grinding. 1. Initial investigations. Ind. Eng. Chem. Res. 48, 2556-2565.

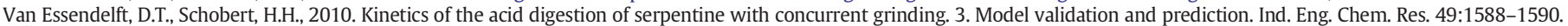
http://dx.doi.org/10.1021/ie901159t.

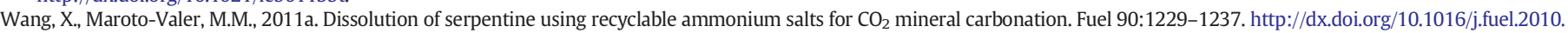
10.040

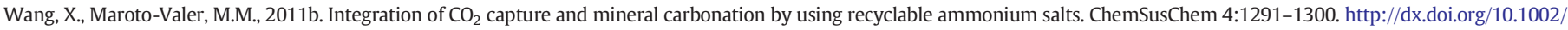
CSSc.201000441.

Wicks, F.J., Whittaker, E.J.W., 1975. A reappraisal of the structures of the serpentine minerals. Can. Mineral. 13, $227-243$.

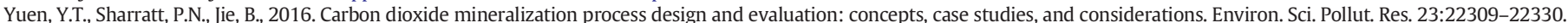
http://dx.doi.org/10.1007/s11356-016-6512-9.

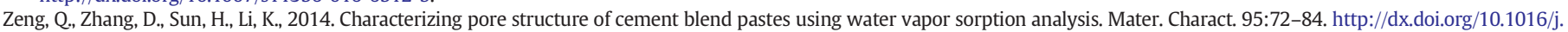
matchar.2014.06.007. 